\title{
Consistency of postglacial geodynamics for the Kattegat region, southern Scandinavia, based on seismological, geological and geodetic data
}

\author{
Søren Gregersen and Peter H. Voss
}

The earthquake map of Denmark is constantly being improved. Together with data from western Sweden and southern Norway it shows more and more convincingly a gradual, scattered earthquake activity across the Kattegat region from low activity in the Precambrian basement of Scandinavia to lack of earthquakes in south-western Denmark and northern Germany. The activity is only partly connected with mapped geological features. The three most recently felt earthquakes in Denmark augment and support this pattern with two or three activity concentrations in the seas around Denmark (Fig. 1). The smoothness and irregularities of this picture must in some way be related to the geological structure as well as to the geodynamic pattern of postglacial uplift mapped from geology and geodesy. Since the dominant stress field, from the lithospheric plate motion is smooth (Gregersen \& Voss 2010), a natural question is whether the picture

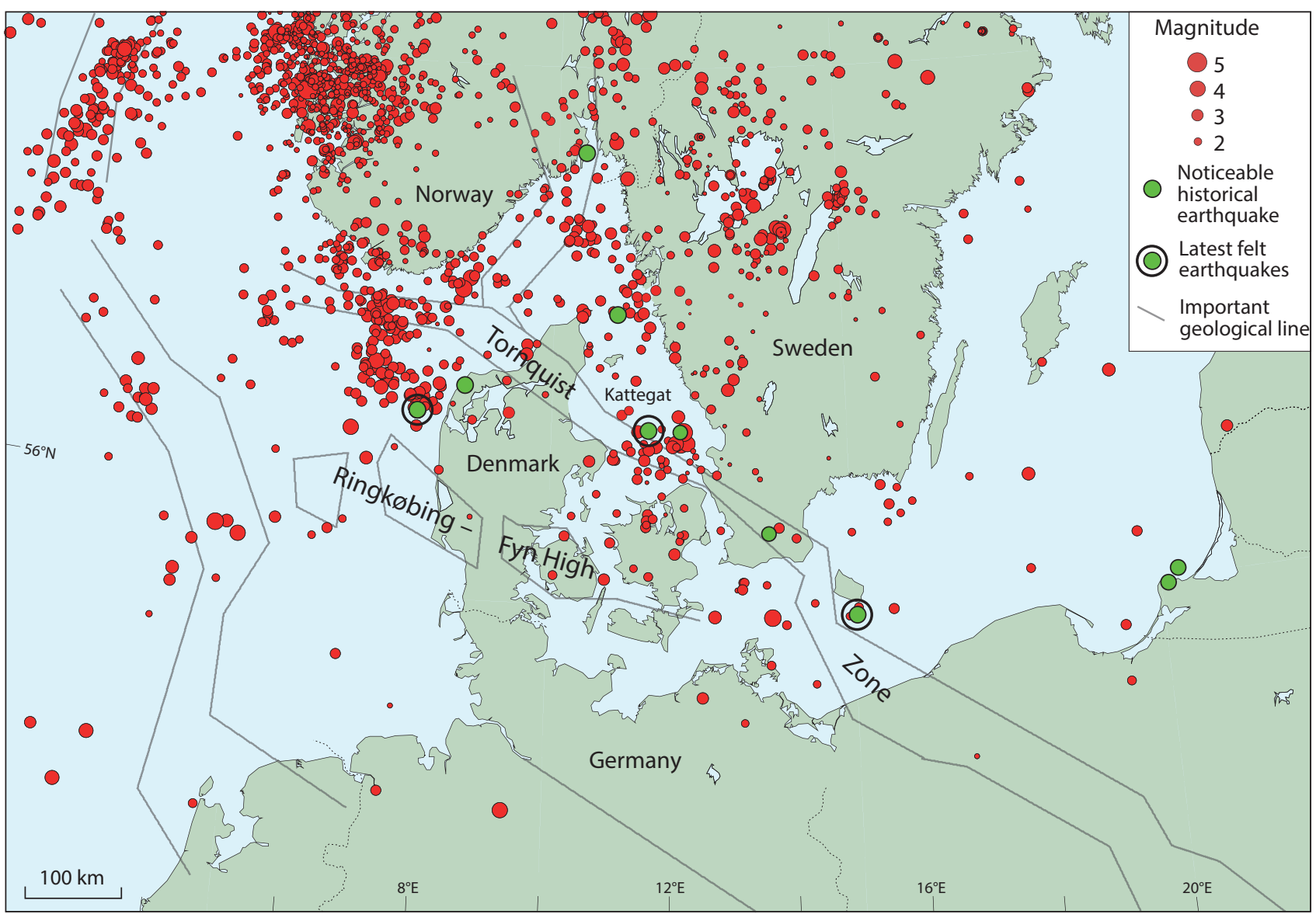

Fig. 1. The latest three felt earthquakes in Denmark shown on the best available earthquake map of the Kattegat and the surrounding regions (Gregersen \& Voss 2014). Little earthquake activity is seen north-east of the gradual margin of the Fennoscandian Shield between the Tornquist Zone and the Ringkøbing-Fyn High. In contrast, no activity is seen in south-western Denmark and north-western Germany. Only a few small earthquakes have been recorded in the south-eastern part of the area shown on the map; this is because only few seismographs are located in that region. 
of postglacial uplift, seen from the geological and geodetic perspective shows local irregularities? The broad-scale uplift pattern in Denmark since the last Ice Age has been known since the review published by Mertz (1924). All later papers have referred to this general pattern of uplift towards the north-east and subsidence towards the south-west with reference to the present sea level. The present paper relates the regional seismological pattern to the smooth and consistent patterns in postglacial geology and geodesy, as well as to the existing local investigations on geodynamics. Interpretations of the measured uplift of shorelines on Læsø, in the middle of the Kattegat (Fig. 2), have given rise to opposing views on regularity versus irregularity between the present authors and Hansen et al. (2012). The measurements show that the elevation of the oldest postglacial shorelines on Læsø fit in the regional pattern with regard to elevation, but not with regard to time. In this paper we propose that the time difference is only apparent.

\section{Uplift patterns}

Recent overviews of the geological evolution of the region of Denmark, including the uplift since the time of flooding, termed the Littorina Sea transgression, have been presented by Christensen (2001) and Noe-Nygaard et al. (2006). The former provided ages for the oldest shorelines, from radiocarbon dating, pollen and human settlement evidence. It is seen that the uplift increases gradually from the south-west towards the north-east (Fig. 2). The general pattern with in- creasing ages towards the north-east has been convincingly argued for by Christensen (2001).

The ages in Fig. 2 are the oldest for each location for the Littorina Sea period that lasted several thousands of years. During this long time period the postglacial uplift of the lithosphere approximately followed the rising water level, within about one metre. Both were influenced by the melting ice sheets after the last Ice Age. The situation, with repeated small transgressions and regressions, was illustrated by Christensen (2001), Noe-Nygaard et al. (2006) and Clemmensen et al. (2012). The latter paper shows that this period of several thousand years ends rather abruptly with a large regression lasting until present time. The start of the regression can be dated by optically stimulated luminescence (OSL), when no later transgressions disturb the dark, covered parts of the beach sediments used for dating. The elevation of raised beaches and ages determined for Anholt (Fig. 2) by Clemmensen $e t$ al. (2012) are interpreted as a period of 'simultaneous' land uplift and sea-level rise for several thousands of years followed by a period of continuing land uplift and slower sea-level changes. This is suggested generalised for the Kattegat region in Fig. 3 with times that are different for different locations.

In Fig. 3 two kinds of arrows are seen. The thick arrow points to the oldest shoreline that has not been disturbed by a transgression. Sediments from this shoreline can be dated by the OSL method. On Anholt it has been dated to 2300 years BC (Clemmensen et al. 2012). The thin arrows point to archaeological time periods which can be dated by pollen

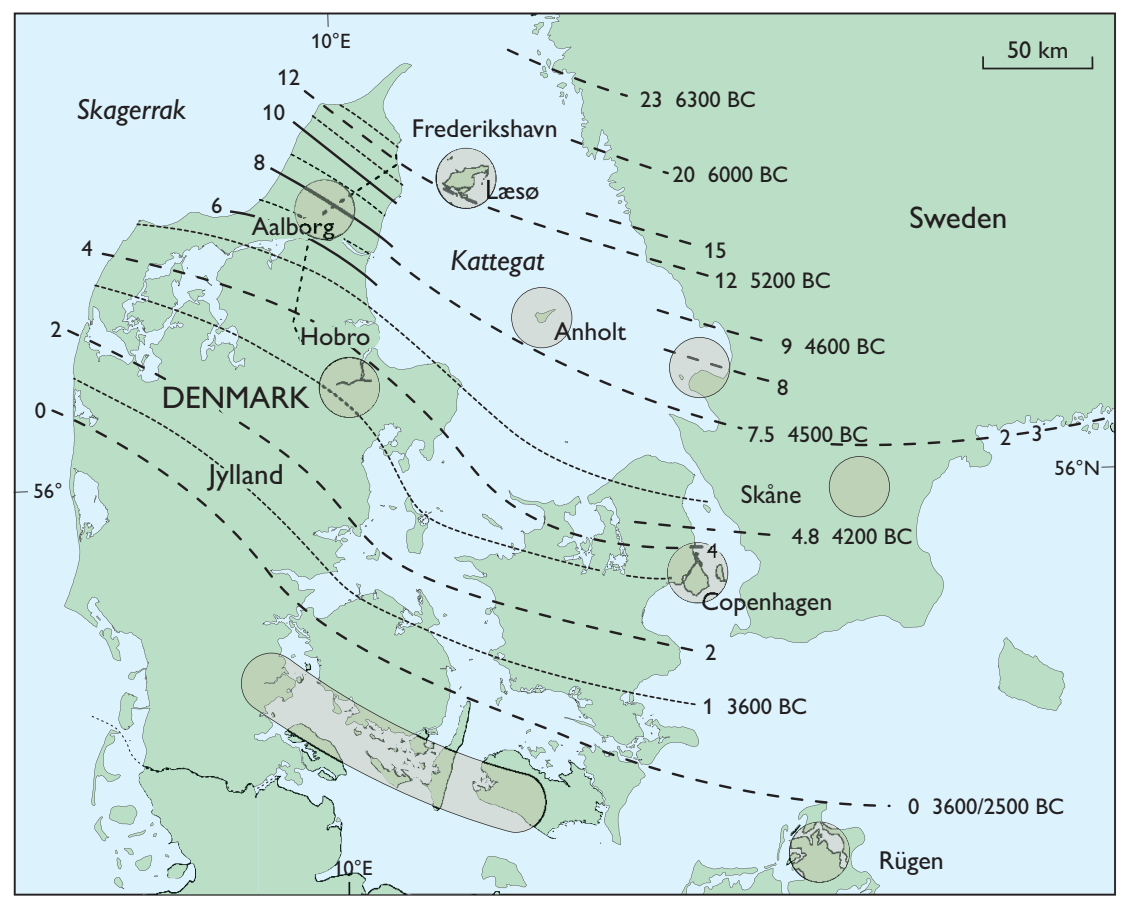

Fig. 2. General picture of the elevation patterns of postglacial shorelines in metres above present sea level, according to Christensen (2001). Shaded circles and zones refer to locations mentioned in the text, where irregularities have been claimed. Ages of highest shorelines of the Littorina Sea, i.e. after the last Ice Age, are from Christensen (2001). This figure is a corrected version of a figure presented by Gregersen \& Voss (2012) and by Gregersen (2014), where the ages were incorrectly quoted. 
Fig. 3. Conceptual model showing the elevation of shorelines in Kattegat as a function of age. The model shows the generalised concept of uplift with minor oscillations in the grey band of the order of one metre from several sources mentioned in the text. The arrows point to age data, thin arrows to archaeological data, thick arrow to OSL data. Only for Anholt older OSL data supplement the archaeological dates.

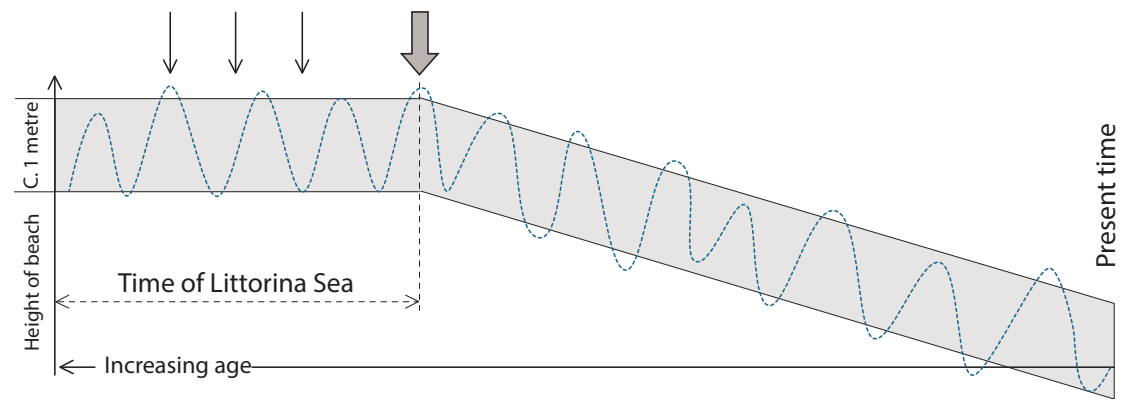

analysis, radiocarbon dating or human settlement indicators for places close to the beach where plants or human remains have survived close to the shoreline or just above it. In Fig. 2 the Anholt age from Christensen (2001) is 4500 years BC, i.e. 2200 years before the OSL age mentioned above. Only in special cases will an older shoreline from within the Littorina Sea time, protected from transgression, show up by OSL dating as in Anholt (Clemmensen et al. 2012).

On Læsø all ages were determined by OSL and all are young compared to regions with similar elevations of the highest shorelines (Fig. 2; Hansen et al. 2012; J.M. Hansen,

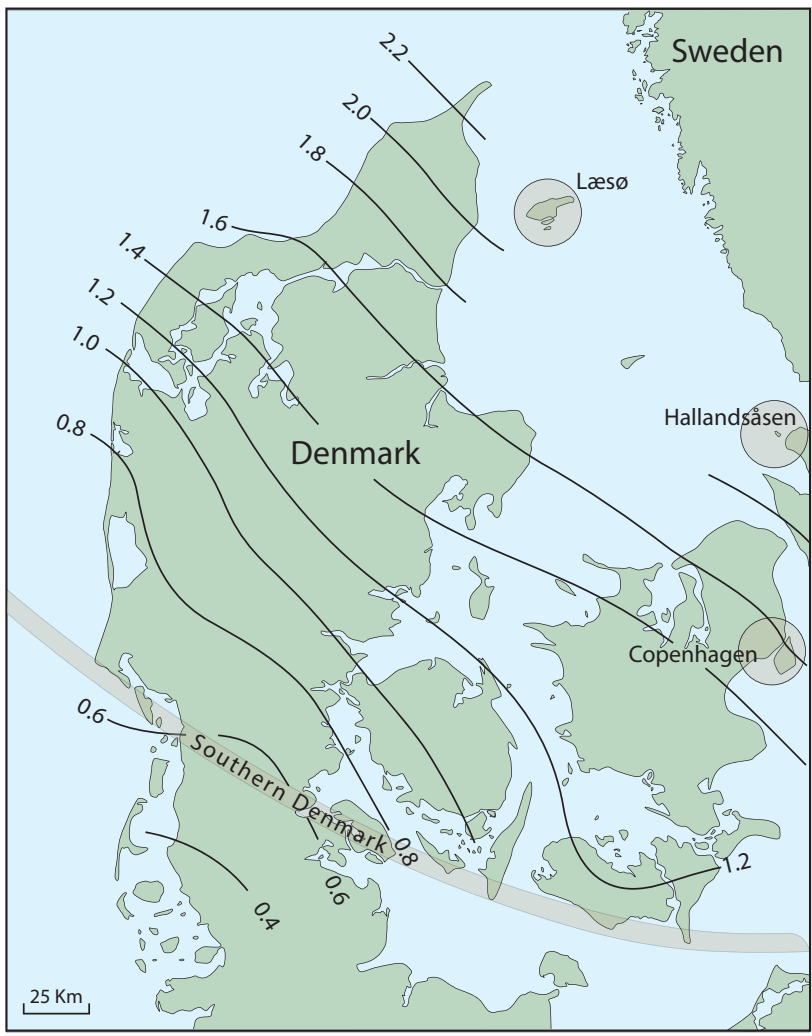

Fig. 4. Generalised uplift velocities (mm/year) from Knudsen et al. (2012) based on levelling, GPS and sea-level gauges. The velocities have been corrected from an earlier version by Gregersen \& Voss (2014). The shaded circles and zones show locations where irregularities have been claimed, and which are discussed in the text. personal communication, 2013-2014). Those authors also suggest that older shorelines are not observed on Læsø because they were eroded by waves. We suggest that this shows that only the right part of Fig. 3 is relevant for Læsø. In contrast, data from both the left and right parts are available from Anholt. Many other regions such as northern Jylland and western Sweden are well described by the left part of Fig. 3 (Christensen 2001, fig. 2; Christensen \& Nielsen 2008). This point was discussed by Gregersen \& Voss (2010, 2012, 2014) and Gregersen (2014) who suggested that the age determinations ought to be redone using the same methods for points of comparable uplift in northern Jylland, on Læsø and in western Sweden (see Fig. 2).

A smooth picture with only small irregularities is also shown by a recent geodetic picture of uplift velocities based on all available data from levelling, global positioning system (GPS) and sea-level gauges (Fig. 4). Both the geological picture illustrated by Fig. 2 and the geodetic picture in Fig. 4 show the main, general features. Geological and physically small irregularities are generalised into the broad-scale regional picture. In addition, the geodetic picture is based on measurements carried out over only approximately 100 years. Updating with greater detail will be appreciated in the future. Figures 2 and 4 indicate regularity so far.

\section{Discussion of irregularities from the literature}

In addition to the irregularity proposed for Læsø, several more irregularities have been proposed for different regions in Denmark (Figs 2, 4). Some of them show irregularities in the sedimentary succession which may be connected to larger-scale postglacial faulting, e.g. the Carlsberg Fault in the Copenhagen area described by Rosenkrantz (1937) and Ovesen et al. (2002) or faulting reported from mid-Jylland by Jakobsen \& Pedersen (2009). Other irregularities could be directly related to the postglacial uplift pattern, as described by Lykke-Andersen \& Borre (2000) and Gregersen \& Schmidt (2001) for the region from Hobro via Aalborg to Frederikshavn or by Hansen et al. (2012) for harbours in 
southern Denmark, based on 100 years of water-level measurements.

The irregularity locations in the middle of Skåne in southern Sweden and on Rügen in northern Germany are based on geodetic measurements. The case in southern Sweden (Pan et al. 1999) has been rejected by Swedish geodesists because of inaccuracy (H.-G. Scherneck, personal communication 2015). The case in northern Germany is based on a personal communication by R. Dietrich in 2008. It was claimed that geodetic levelling indicates similar changes in uplift rates as those seen in northern Jylland by Lykke-Andersen \& Borre (2000), but it awaits further confirmation by geodesists. The claims by Mörner (2003) on postglacial earthquakes near Hallandsåsen, based on geological irregularities were taken up on a field excursion in the summer of 2013 by 12 international seismologists on the initiative of the first author of this article. The outcome was "possible but not probable".

\section{Conclusion}

The discussion as to whether the evidence for lack of major irregularities in the geology and geodesy fields is sufficiently strong to be significant is heated (Hansen et al. 2012; Gregersen \& Voss 2012). Recent papers by Gregersen \& Voss $(2012,2014)$ and by Gregersen (2014) claim that the irregularities are so small compared to the uncertainties in the measurements that they are insignificant, and thereby not disturbances of the regularity. They are only possibilities. They need supporting evidence in the form of irregularities in the generalised geodynamics. Our view is that such supporting evidence is lacking. The consequence of the consistency of the regional geophysical fields is that the short term, thousand-years evidence from seismology adequately describes the geodynamics and its irregularities.

We suggest that the use of different methods for dating of the shorelines results in that different phases of the uplift are dated. The OSL dates reflect the last influence of the waves on the loose sediments of the shore, whereas the archaeological dates reflect the several thousand-year long Littorina Sea time when land plants left remains in the dry ground near the shoreline. The age determinations are different because different phenomena were measured.

\section{References}

Christensen, C. 2001: Kystbosættelse og havniveauændringer i stenalderen. In: Jensen, O.L., Sørensen, S.A. \& Hansen, K.M. (eds): Danmarks jægerstenalder - status og perspektiver, 183-193. Hørsholm: Hørsholm Egns Museum.

Christensen, C. \& Nielsen, A.B. 2008: Dating the Littorina Sea shore levels in Denmark on the basis of data from a Mesolithic coastal settlement on Skagens Odde, northern Jutland. Polish Geological Institute Special Papers 23, 27-38.

Clemmensen, L., Nielsen, L. \& Konnerup-Madsen, J. 2012: Anholt. Geoviden 2012/1, 20 pp.

Gregersen, S. 2014: Jordskælvsrisiko i Danmark? - forslag til fremtidens studier. Kvant 2014/2, 30-34.

Gregersen, S. \& Schmidt, K. 2001: Tektonik i Danmark. Sorgenfrei-Tornquist Zonen. Geologisk Nyt 2001/1, 16-17.

Gregersen, S. \& Voss, P. 2010: Irregularities in Scandinavian postglacial uplift/subsidence in time scales tens, hundreds, thousands of years. Journal of Geodynamics 50, 27-31.

Gregersen, S. \& Voss, P.H. 2012: Efforts to include geological and geodetic observations in the assessment of earthquake activity in Denmark. Geological Survey of Denmark and Greenland Bulletin 26, 41-44.

Gregersen, S. \& Voss, P.H. 2014: Review of some significant claimed irregularities in Scandinavian postglacial uplift on timescales of tens to thousands of years - earthquakes in Denmark? Solid Earth 5, 109-119.

Hansen , J.M., Aagaard, T. \& Binderup, M. 2012: Absolute sea levels and isostatic changes of the eastern North Sea to central Baltic region during the last 900 years. Boreas 41, 180-208.

Jakobsen, P.R. \& Pedersen, S.A.S. 2009: Fracture valleys in central Jylland - a neotectonic feature. Geological Survey of Denmark and Greenland Bulletin 17, 33-36.

Knudsen, P., Engsager, K. \& Khan, S.A. 2012: Dokumentation for beregning af ny uplift-model 2011, 19 pp. Unpublished report. Lyngby: DTU Space.

Lykke-Andersen, H. \& Borre, K. 2000: Aktiv tektonik i Danmark - der er liv i Sorgenfrei-Tornquist Zonen. Geologisk Nyt 2000/6, 12-13.

Mertz, E.L. 1924: Oversigt over De sen- og postglaciale Niveauforandringer i Danmark. Danmarks Geologiske Undersøgelse II. Række 41, 49 pp.

Mörner, N.-A. 2003: Paleoseismicity of Sweden - a novel paradigm, 320 pp. Stockholm: University of Stockholm.

Noe-Nygaard, N., Knudsen, K.L., \& Houmark-Nielsen, M. 2006: Fra istid til og med jægerstenalder. In: Sand-Jensen, K. \& Larsen, G. (eds): Naturen i Danmark, Geologien, 303-331. Copenhagen: Gyldendal.

Ovesen, N.K., Blem, H., Gregersen, S., Møller, H.M.F. \& Frederiksen, J.K. 2002: Recente terrænbevægelser i København. Dansk Geoteknisk Forenings Bulletin 19, 183-192.

Pan, M., Sjöberg, L.E., Talbot, C. \& Asenjo, E. 1999: GPS measurements of crustal deformation in Skåne, Sweden between 1989 and 1996. GFF 121, 67-72.

Rosenkrantz, A. 1937: Bemærkninger om det østsjællandske Daniens Stratigrafi og Tektonik. Meddelelser fra Dansk Geologisk Forening 9 , $199-212$.

\footnotetext{
Authors' address

Geological Survey of Denmark and Greenland, Øster Voldgade 10, DK-1350 Copenhagen K, Denmark. E-mail: sg@geus.dk
} 